\section{Quantitative Distribution of Candidatus Liberibacter asiaticus in the Aerial Parts of the Huanglongbing-infected Citrus Trees in Texas}

\author{
Madhurababu Kunta ${ }^{1}$ and John V. da Graça \\ Texas A\&M University-Kingsville, Citrus Center, 312 N. International \\ Boulevard, Weslaco, TX 78599
}

Nasir S.A. Malik

USDA-ARS, ERRC, 600 E Mermaid Lane, Wyndmoor, PA 19038-8598

\section{Eliezer S. Louzada and Mamoudou Sétamou}

Texas A\&M University-Kingsville, Citrus Center, 312 N. International Boulevard, Weslaco, TX 78599

Additional index words. grapefruit, Huanglongbing, quantitative polymerase chain reaction, sweet orange

\begin{abstract}
The Asian citrus psyllid, Diaphorina citri Kuwayama, one of the known vectors for citrus greening disease or Huanglongbing (HLB) pathogens, has been present in Texas for over a decade, but the detection of the disease is recent. HLB has been confirmed in only two adjacent commercial citrus groves of grapefruit and sweet orange. A study was conducted to compare the population of Candidatus Liberibacter asiaticus (CLas) cells in different plant parts including peduncle, columella, leaves, seeds, young shoots, flower buds, flowers, and bark of 6-year-old known infected grapefruit and sweet orange trees. The bacterial population was estimated using a previously described grand universal regression equation $Y=13.82-0.2866 X$, where $Y$ is the $\log$ of the target copy number and $X$ is the $\mathrm{Ct}$ (threshold cycle) of the assay. Except for bark tissue, there was no significant difference in the concentration of CLas cells in other plant parts between the two cultivars. Within the cultivar, the bacterial concentration also varied with the plant part, with peduncle, columella, midrib having significantly higher titer of CLas compared with other plant parts. The obtained results here are in agreement with previous studies conducted on Florida samples, but the consistently lowest bacterial titer recorded in young shoots, leaf blade, and especially leaf margins relative to the midrib has never been previously reported.
\end{abstract}

Huanglongbing is considered to be the most destructive citrus disease worldwide, having caused devastating economic damage to citrus in Asia and Africa for more than 100 years (Aubert, 1992) and more recently in Brazil and Florida (Bové, 2006; da Graça and Korsten, 2004).

HLB is associated with phloeminhabiting Gram-negative $\alpha$-Proteobacteria (Jagoueix et al., 1994), specifically, CLas, 'Ca. L. africanus' (CLaf), and 'Ca. L. americanus' (CLam) (Bové, 2006). CLas and CLam are naturally vectored by the Asian citrus psyllid, Diaphorina citri Kuwayama (Hemiptera: Liviidae) (Capoor et al., 1967) and CLaf is vectored by the African citrus psyllid, Trioza erytrea Del Guercio (McClean

\footnotetext{
Received for publication 26 Sept. 2013. Accepted for publication 8 Nov. 2013.

We thank Mr. Omar Vazquez, graduate student at TAMUK-Citrus Center, Weslaco, TX, for drawing of figures.

${ }^{1}$ To whom reprint requests should be addressed; e-mail madhura.kunta@tamuk.edu.
}

that there is a possibility of overestimation of bacterial cells because quantitative polymerase chain reaction (qPCR) cannot differentiate live from dead cells.

A similar study using both qPCR and conventional PCR (cPCR) to amplify $16 \mathrm{~S}$ rDNA showed that CLas is unevenly distributed in infected bark, leaf midribs, roots, and floral and fruit parts, ranging from 14 to $137,031 \mathrm{cells} / \mu \mathrm{g}$ of the tissue, with relatively high populations in fruit peduncles, but no bacteria were detected in endosperm and embryo of the seed (Tatineni et al., 2008). However, Hilf (2011) has detected bacteria in seedcoats. Furthermore, Tatineni et al. (2008) suggested that knowledge of pathogen distribution is essential to choose appropriate samples for diagnosis, understand virulence mechanisms, and develop disease management strategies.

Teixeira et al. (2008) reported that bacterial concentrations of CLam were highest in leaves with blotchy mottle, ranging from $1.1 \times 10^{6}$ to $2.8 \times 10^{7}$. Higher concentrations were observed in leaves at the distal ends of branches compared with those at the proximal ends, close to the trunk. Moreover, $84 \%$ of the leaves with zinc deficiency symptoms were PCR-positive. They observed that when genuine zinc deficiency is present, it affects practically all of the trees in an orchard but when HLB first begins to affect an orchard, the deficiency-like symptoms will affect few trees and will be widely scattered.

A reliable, rapid, and sensitive qPCR test to detect and identify $\mathrm{Ca}$. Liberibacter spp. in HLB-infected citrus trees, which is 100 -fold more sensitive than cPCR, was developed by Li et al. (2006). Ca. Liberibacter spp. genome equivalents were estimated in citrus using a grand regression equation that incorporate all of the sample effects such as host tissue type, host species, geographic location, tissue storage, DNA quality, inhibitors, and PCR amplification efficiency (Li et al., 2008). However, its limitation for pathogen detection is that the 16S rDNA copy number must be greater than $2.27 \times 10^{5} / \mathrm{g}$ of host tissue, which is below the threshold concentration for symptom development. Furthermore, qPCR of root samples using $16 \mathrm{~S}$ primers amplifies non-specific target (Kunta et al., unpublished data).

HLB disease symptoms may be confused with nutrient deficiencies or other disease symptoms (Bové, 2006). Moreover, CLas is unevenly distributed in the phloem of the infected citrus plants (Garnier and Bové, 1993), and consistent detection of the disease depends on plant tissue with high bacterial titers. Gottwald et al. (2008) showed that in the field-grown citrus trees, often irregular distribution of HLB symptoms is seen in individual branches as symptoms develop, and CLas is readily PCR-detectible from several tissue samples throughout the tree. They concluded that CLas infection is systemic or nearly completely systemic in the trees; however, the bacterial concentrations in different portions of the tree may be below detectible levels. Furthermore, a recent study 
showed that temperature influences infection and establishment of CLas and CLam in citrus plants where the highest CLas titers were observed in citrus plants maintained at $22 / 27{ }^{\circ} \mathrm{C}$ and CLas concentrations were negatively affected by a daily temperature regime of $27 / 32{ }^{\circ} \mathrm{C}$ (Gasparoto et al., 2012). Additionally, it was reported that continuous exposure to 40 to $42{ }^{\circ} \mathrm{C}$ for a minimum of $48 \mathrm{~h}$ significantly reduced CLas titers or even eliminated CLas from infected citrus seedling (Hoffman et al., 2013). In Texas, HLB is a recent introduction, and it is confirmed present only in two adjacent groves in San Juan, TX, and a residential grapefruit tree in Mission, TX; therefore, it is very important to establish CLas distribution in citrus tree parts under field conditions where the temperatures are consistently high and different from Florida or elsewhere. According to 19812010 temperature data for June to August from the National Weather Service (http:// www.weather.gov), the average and high temperatures were on average higher by 4.4 and $5.7^{\circ} \mathrm{F}$, respectively, in south Texas compared with central Florida. Moreover, along with temperature, factors such as nutrient status of the trees, psyllid populations, soil conditions, irrigation regime, and presence of Phytophthora may influence the distribution of CLas in the field trees. This is the first study that was conducted to estimate the CLas concentrations in different tree parts of field-grown grapefruit and sweet orange trees in Texas.

\section{Materials and Methods}

Plant material. HLB-infected tissue samples (Table 1) were collected during June to July 2012 from six trees each of 6-year-old naturally infected field-grown 'Valencia' sweet orange and 'Rio Red' grapefruit trees on sour orange rootstock with symptomatic branches in a commercial citrus grove in San Juan, TX. Fruit, young leaves, young shoots, and flower buds were collected from symptomatic branches with classic leaf mottle that were previously confirmed positive by qPCR for the presence of CLas. A total of 11 and five peduncle, 33 and 19 columella, 10 and 13 leaf midrib, 10 and 22 bark, nine and seven seed, nine and eight leaf blade middle parts, and 10 and 10 leaf blade edge tissue samples from grapefruit and sweet orange, respectively, were used in CLas quantitative distribution analysis. In sweet orange, no young plant parts were available at the time of collection and were not collected from all six trees and only two young tissue samples per each of leaf, flower bud, and shoot were collected from two grapefruit trees. Six flower samples were collected only from sweet orange trees because they were not available from grapefruit trees. Samples were collected because citrus trees tested positive for CLas in the groves and because citrus phenology varies with time, all plant developmental stages were not present for sampling at a given time. Therefore, the number of samples of each type from the cultivars was random and a completely randomized design was used in the analysis.

DNA extraction. Total DNA was isolated using the Qiagen DNeasy Plant Mini Kit from $200 \mathrm{mg}$ chopped tissue of different plant parts. The tissue was placed in a 2-mL lysing matrix A tube (MP Biomedicals, Santa Ana, CA) with extraction buffer and pulverized for 3 min using a Mini-Beadbeater-96 (Biospec Products Inc., Bartlesville, OK). The extract of total DNA was eluted in $100 \mu \mathrm{L}$ nuclease-free water.

Estimation of Candidatus Liberibacter asiaticus population in different tissues. For the detection and quantification of CLas, multiplex qPCR assays ( $\mathrm{Li}$ et al., 2006) were performed using a HLBfpr primer-probe set on $2 \mu \mathrm{L}$ total DNA extract in a $25 \mu \mathrm{L}$ reaction using a SmartCycler II (Cepheid, Sunnyvale, CA) or ABI 7500 Fast thermocycler (Life Technologies). A citrus mitochondrial cytochrome oxidase (COX)-based primer probe set COXfpr ( $\mathrm{Li}$ et al., 2006) was used as a positive internal control. All reactions contained known positive control DNA, healthy plant DNA, and non-template water control. The presence of the target sequences in the DNA extracts were confirmed based on the $\mathrm{Ct}$ values obtained. The $\mathrm{Ct}$ values obtained were incorporated into the universal regression equation as described by Li et al. (2008): $Y=13.82-0.2866 X$ (where $Y$ is the $\log$ of the target copy number and $X$ is the $\mathrm{Ct}$ value) to calculate the CLas genome equivalents present in the DNA extracts from different tissue parts and the number obtained was converted into CLas genome equivalents per gram of the tissue. Data were subjected to a two-way analysis of variance (ANOVA) to evaluate the effect of cultivar, plant part from which the tissue was collected, and their interaction on bacterial concentration using PROC GLM of SAS (SAS Institute, Cary, NC). Before analysis, data were tested for normality and homogeneity of variances. In case of violation of ANOVA assumption, data were logtransformed before analysis. Whenever significant $F$ values were obtained, treatment means were separated using the Student Newman Keuls test (Zar, 1999). Data were subsequently back-transformed and reported as actual concentration.

\section{Results}

Analysis of variance showed that $C a$. L. asiaticus concentrations per gram of fresh tissue was significantly affected by the interaction between cultivar and plant part $(F=3.46 ;$ df $=6,187, P=0.0029)$. Thus, the effects of plant part on CLas concentrations were evaluated separately for each host cultivar. Similarly, the comparison of bacterial titers between grapefruit and sweet orange was conducted separately for each plant part.

Ca. L. asiaticus in different tissues of grapefruit. The genome equivalents of CLas per gram of fresh tissue varied from $1.18 \times$ $10^{6}$ in the young shoot to $2.95 \times 10^{9}$ in the peduncle. Tissue samples including peduncle, columella, leaf midrib with petiole, bark, and seeds consistently produced lower $\mathrm{Ct}$ values containing higher CLas genome equivalents (Table 1). The young tissue samples including leaves, flower buds, and shoots consistently showed lower CLas concentrations than mature tissue. Additionally, there was no significant difference between leaf blade edges and leaf blade middle part tissues, and the CLas concentrations were much lower compared with the leaf midrib. The distribution of CLas in grapefruit tree aboveground parts is graphically represented in Fig. 1.

Ca. L. asiaticus in different tissues of sweet orange. Ca. L. asiaticus was readily detected in different aboveground tree parts and the bacterial titers ranged from $4.40 \times 10^{9}$

Table 1. Different plant parts used in the quantification of Candidatus Liberibacter asiaticus by quantitative polymerase chain reaction assay from Huanglongbing-infected field-grown 'Valencia' sweet orange and 'Rio Red' grapefruit trees in Texas

\begin{tabular}{|c|c|c|c|c|}
\hline $\begin{array}{l}\text { Grapefruit } \\
\text { Tissue }\end{array}$ & No. samples tested & Ca. L. asiaticus/g of fresh tissue ${ }^{z}$ & $\begin{array}{c}\text { Sweet orange } \\
\text { No. of samples tested }\end{array}$ & Ca. L. asiaticus/g of fresh tissue \\
\hline Peduncle & 11 & $2.95 \times 10^{9} \mathrm{a} \mathrm{A}$ & 5 & $4.40 \times 10^{9} \mathrm{a} \mathrm{A}$ \\
\hline Columella & 33 & $1.68 \times 10^{9} \mathrm{a} \mathrm{A}$ & 19 & $1.58 \times 10^{9} \mathrm{ab} \mathrm{A}$ \\
\hline Leaf midrib & 10 & $1.11 \times 10^{9} \mathrm{ab} \mathrm{A}$ & 13 & $1.09 \times 10^{9} \mathrm{ab} \mathrm{A}$ \\
\hline Bark & 10 & $2.13 \times 10^{8} \mathrm{abc} \mathrm{A}$ & 22 & $2.80 \times 10^{6} \mathrm{c} \mathrm{B}$ \\
\hline Seed & 9 & $2.08 \times 10^{8} \mathrm{abc} \mathrm{A}$ & 7 & $3.72 \times 10^{7}$ bc A \\
\hline Leaf blade middle part & 9 & $5.82 \times 10^{7}$ bcd A & 8 & $6.41 \times 10^{6} \mathrm{c} \mathrm{A}$ \\
\hline Leaf blade edge & 10 & $2.93 \times 10^{7} \mathrm{~cd} \mathrm{~A}$ & 10 & $8.36 \times 10^{6} \mathrm{c} \mathrm{A}$ \\
\hline Flower & 0 & . & 6 & $7.18 \times 10^{6} \mathrm{c}$ \\
\hline Young leaf & 2 & $4.72 \times 10^{6} \mathrm{de}$ & 0 & . \\
\hline Flower bud & 2 & $1.93 \times 10^{6} \mathrm{e}$ & 0 & . \\
\hline Young shoot & 2 & $1.18 \times 10^{6} \mathrm{e}$ & 0 & \\
\hline
\end{tabular}

${ }^{\mathrm{z}}$ Means followed by the same small upper case letter within each column are not significantly different at $P=0.05$ [Student Newman Keuls (SNK) test]; for each plant part, means followed by the same capital letter are not significantly different at $P=0.05$ (SNK test). 

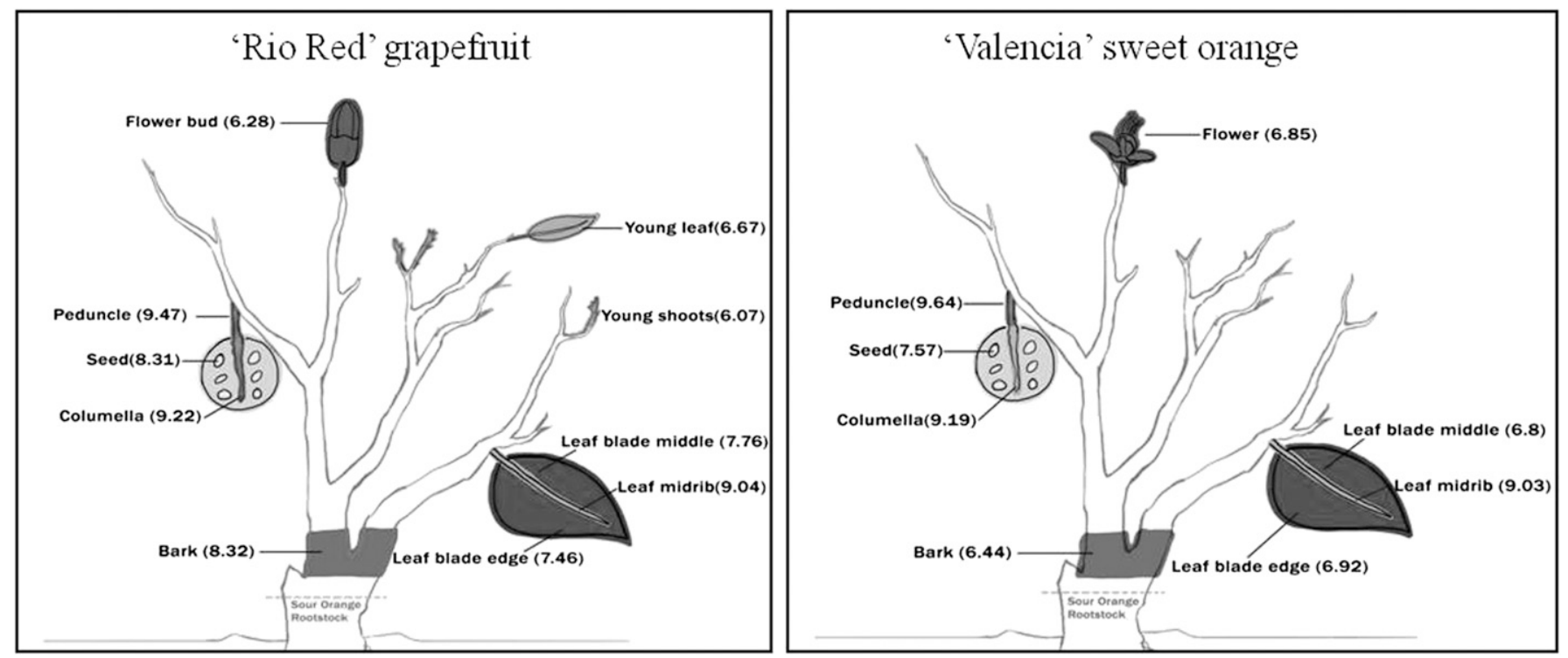

Fig. 1. Distribution of $\mathrm{Ca}$. L. asiaticus in the aboveground tree part tissues of field-grown 6-year-old naturally infected 'Rio Red' grapefruit and 'Valencia' sweet orange trees in Texas. Values in parentheses represent $\log$ (CLas) of various plant parts.

to $7.18 \times 10^{6}$ with the highest titer recorded for peduncle (Table 1). In general, peduncle, columella, and leaf midrib with petiole produced lower $\mathrm{Ct}$ values with higher CLas genome equivalents. The tissue samples including bark, leaf blade middle part, leaf blade edges, and flowers showed lower CLas populations, whereas seeds showed intermediate levels of CLas concentrations. A graphic representation of CLas populations in sweet orange aerial plant parts is shown in Fig. 1.

Comparison of $\mathrm{Ca}$. L. asiaticus titers in grapefruit and sweet orange for different plant parts. With the exception of bark tissue in which significantly higher bacterial titers were recorded for grapefruit compared with sweet orange $(F=17.49$; df $=1,30, P=$ 0.0002 ) and juvenile tissues (not sampled from sweet orange), no significant differences were observed for other plant parts between the two host plants.

\section{Discussion}

With the exception of bark in which higher $\mathrm{Ca}$. L. asiaticus concentration was recorded in HLB-infected sweet orange trees relative to their grapefruit counterparts and juvenile tissue (not sampled from sweet orange), we found no significant differences in bacterial titer between the two cultivars for the other plant tissues. It is important to note that a recent study reported that there is a significantly lower acquisition of CLas from grapefruit by $D$. citri compared with other citrus cultivars (Pelz-Stelinski and Stelinski, 2013). Furthermore, previous studies have shown that the transmission of CLas by adult D. citri is lower if the pathogen was acquired as adults compared with acquire as nymphs (Stelinski et al., 2010). Recently, it was reported that different infected scions of cultivars shows varied levels of CLas concentrations suggesting that there is a potential for using scions with increased tolerance to effectively manage the disease (Stover and McCollum, 2011).

Current protocols to detect CLas predominantly use DNA extracts from mature symptomatic leaf midrib. We found that both in sweet orange and grapefruit, leaf midribs harbor very high CLas concentrations and there is no significant difference in CLas populations among leaf midrib, columella, and peduncle tissues. Moreover, the leaf blade middle parts and leaf blade edges contained lower bacterial concentrations than midrib. Based on these results, we conclude that our current practices of using leaf midrib tissue to detect CLas is appropriate and leaf midribs along with petiole are a good source of aboveground tree tissue to detect CLas. Furthermore, it is important to note that young tissue including leaves, shoots, and flower buds contain the lowest bacterial concentrations.

Understanding the movement of the bacterium inside the tree and its distribution in different plant parts is critical to understanding virulence mechanism and to manage the spread of the disease (Tatineni et al., 2008). It is important to note that on average there were lower CLas populations in Texas citrus tree tissues compared with an average of $10^{10}$ CLas genomes per gram of tissue ( $\mathrm{Li}$ et al., 2009) that were reported in Florida tissue samples. However, we do not know whether fluctuations of environmental conditions during different seasons in a year will affect this finding because the study was only conducted during June to July 2012 and was not done at different times during the year.

Since its first detection, in Texas, in Jan. 2012 (Kunta et al., 2012), we did not detect the disease outside of the quarantine zone except in a residential grapefruit tree in downtown Mission, TX. We speculate that general low-level acquisition of CLas from grapefruit by $D$. citri, environmental conditions in Texas such as high temperatures, proactive $D$. citri control strategies, and early detection of CLas and tree removal might have contributed to prevent the spread of the disease. The findings of this study provide a useful tool for the Texas citrus industry for using appropriate tissue for efficient CLas detection so one could take necessary actions to prevent further spread of the disease.

\section{Literature Cited}

Aubert, B. 1992. Citrus greening disease, a serious limiting factor for citriculture in Asia and Africa. Proc. Intern. Soc. Citricult. p. 817-820.

Bové, J.M. 2006. Huanglongbing: A destructive, newly emerging, century-old diseases of citrus. J. Plant Pathol. 88:7-37.

Capoor, S.P., D.G. Rao, and S.M. Viswanath. 1967. Diaphorina citri Kuway., a vector of the greening disease of citrus in India. Ind. J. Agr. Sci. 37:572-576.

da Graça, J.V. and L. Korsten. 2004. Citrus huanglongbing: Review, present status and future strategies, p. 229-245. In: Naqvi, S.A.M.H. (ed.). Diseases of fruits and vegetables. Vol I. Kluwer.

French, J.V., C.J. Kahlke, and J.V. da Graça. 2001. First record of the Asian citrus psylla, Diaphorina citri Kuwayama (Homoptera: Psyllidae), in Texas. Subtrop. Plant Sci. 53:14-15.

Garnier, M. and J.M. Bové. 1993. Citrus greening disease and the greening bacterium. Proc. of 12 th Conference IOCV, IOCV, Riverside, CA. p. 212-219.

Gasparoto, M.C.G., H.D. Coletta-Filho, R.B. Bassanezi, S.A. Lopes, S.A. Lourenço, and L. Amorim. 2012. Influence of temperature on infection and establishment of 'Candidatus Liberibacter americanus' and 'Candidatus Liberibacter asiaticus' in citrus plants. Plant Pathol. 61:658-664.

Gottwald, T.R. 2010. Current epidemiological understanding of citrus huanglongbing. Annu. Rev. Phytopathol. 48:119-139.

Gottwald, T.R., S. Parnell, E. Taylor, K. Poole, J. Hodge, A. Ford, L. Therrien, S. Mayo, and M. Irey. 2008. Within-tree distribution of Candidatus Liberibacter asiaticus. Proc. of 
the International Conf. on Huanglongbing (IRCHLB), Florida Citrus Mutual, Orlando, FL. p. 310 .

Halbert, S.E. 2005. The discovery of huanglongbing in Florida. Proc. of the 2nd International Citrus Canker and Huanglongbing Research Workshop, Orlando, FL. p. 50.

Hilf, M. 2011. Colonization of citrus seed coats by 'Candidatus Liberibacter asiaticus': Implications for seed transmission of the bacterium. Phytopathology 101:1242-1250.

Hoffman, M.T., M.S. Doud, L. Williams, M. Zhang, F. Ding, E. Stover, D. Hall, S. Zhang, L. Jones, M. Gooch, L. Fleites, W. Dixon, D. Gabriel, and Y. Duan. 2013. Heat treatment eliminates 'Candidatus Liberibacter asiaticus' from infected citrus trees under controlled conditions. Phytopathology 103:15-22.

Jagoueix, S., J.M. Bové, and M. Garnier. 1994. The phloem-limited bacterium of greening disease of citrus is a member of the $\alpha$ subdivision of the Proteobacteria. Intl. J. Syst. Bacteriol. 44:379386.

Knapp, J., S. Halbert, R. Lee, M. Hoy, R. Clark, and M. Kessinger. 1998. The Asian citrus psyllid and citrus greening disease. Citrus Ind. 79:28-29.

Kumagai, L.B., C.S. LeVesque, C.L. Blomquist, K. Madishetty, Y. Guo, P.W. Woods, S. RooneyLatham, J. Rascoe, T. Galindo, and D. Schnabel.
2013. First report of Candidatus Liberibacter asiaticus associated with citrus Huanglongbing in California. Plant Dis. 92:283.

Kunta, M., M. Sétamou, M. Skaria, J. Rascoe, W. Li, M. Nakhla, and J.V. da Graça. 2012. First report of citrus Huanglongbing in Texas. Phytopathology 102:S4.66.

Li, W., J.S. Hartung, and L. Levy. 2006. Quantitative real-time PCR for detection and identification of Candidatus Liberibacter species associated with citrus huanglongbing. J. Microbiol. Methods 66:104-115.

Li, W., L. Levy, and J.S. Hartung. 2009. Quantitative distribution of 'Candidatus Liberibacter asiaticus' in citrus plants with citrus huanglongbing. Phytopathology 99:139-144.

Li, W., D. Li, E. Twieg, J.S. Hartung, and L. Levy. 2008. Optimized quantification of unculturable Candidatus Liberibacter spp. in host plants using real-time PCR. Plant Dis. 92:854-861.

McClean, A.P.D. and P.C.J. Oberholzer. 1965. Citrus psylla, a vector of greening disease of sweet orange. S. Afr. J. Agr. Sci. 8:297-298.

Niemeyer, M., M. Palma, L. Ribera, and F. Adcock. 2007. Economic impact of greening on the Texas citrus industry. Center for North American Studies (CNAS), Department of Agricultural Economics, Texas A\&M University. CNAS Issue Brief 2007-01. 12 Feb. 2007. $<$ http://cnas.tamu.edu/Economic\%20Impacts\%
20 of $\% 20$ Greening $\% 20$ on $\% 20$ Texas $\% 20$ Citrus $\%$ 20Final.pdf $>$.

Pelz-Stelinski, K.S. and L.L. Stelinski. 2013. Factors influencing transmission of Liberibacter bacteria by Asian citrus psyllid. Citrus Ind. 94:18-20.

Stelinski, K.S., R.H. Brlansky, T.A. Ebert, and M.E. Rogers. 2010. Transmission parameters for Candidatus Liberibacter asiaticus by Asian citrus psyllid (Hemiptera: Psyllidae). J. Econ. Entomol. 103:1531-1541.

Stover, E. and G. McCollum. 2011. Incidence and severity of Huanglongbing and Candidatus Liberibacter asiaticus titer among field-infected citrus cultivars. HortScience 46:1344-1348.

Tatineni, S., U.S. Sagaram, S. Gowda, C.J. Robertson, W.O. Dawson, T. Iwanami, and N. Wang. 2008. In plant distribution of 'Candidatus Liberibacter asiaticus' as revealed by polymerase chain reaction (PCR) and real-time PCR. Phytopathology 98:592-599.

Teixeira, D.C., C. Saillard, C. Couture, E.C. Martins, N.A. Wulff, S. Jaquoueix, P.T. Yamamota, A.J. Ayres, and J.M. Bové. 2008. Distribution and quantification of Candidatus Liberibacter americanus, agent of huanglongbing disease of citrus in São Paulo State, Brasil, in leaves of an affected sweet orange tree as determined by PCR. Mol. Cell. Probes 22:139-150.

Zar, J.H. 1999. Biostatistical analysis. 4th Ed. Prentice Hall, Upper Saddle River, NJ. 